\title{
Comparison of clinical, immunological and virological markers in patients with HTLV-1 / HIV-1 co-infection with those with mono-infection
}

\author{
D Dhasmana*, A Puri, K Buell, G Taylor \\ From 17th International Conference on Human Retroviruses: HTLV and Related Viruses \\ Trois Ilets, Martinique. 18-21 June 2015
}

This is a study of the HTLV-1/HIV-1 co-infected cohort attending the National Centre for Human Retrovirology in London. In a retrospective analysis, demographic, clinical, immunological and virological data was described. A subgroup of patients on combination antiretroviral therapy (cART) for more than twelve months with an undetectable HIV viral load was identified and compared to a matched HTLV-1 mono-infected group. In an ongoing prospective study, HIV-1 mono-infected patients are recruited and virological and immunological parameters compared to the HTLV/HIV co-infected and HTLV mono-infected groups. 29 co-infected patients had a median age of 47 years, $55 \%$ were male and over $80 \%$ identified with the Black - African/Caribbean ethnic group. The median time on cART was 6 months. CD4/CD4\% cell counts were lower in stable co-infected patients $(508$ cells $/ \mathrm{mm} 3, \mathrm{p}=0.2 / 27.9 \%, \mathrm{p}<0.1)$ than HTLV mono-infected patients (941 cells/mm3/46.2\%). There was a significant trend towards increased markers of $\mathrm{T}$ cell activation (TCA) in co-infected patients (Table 1), when compared to TCA markers in either mono-infected group. There were no statistically significant differences in pro-inflammatory cytokines between co-infected and mono-infected patients. However, there was a trend towards higher median interleukin-2 and gamma interferon concentrations in the co-infected group. Response to cART was not blunted in co-infection, and there was normalisation of CD4 counts over 12 months. In one patient absolute HTLV pVL (pro-viral load) increased 12 months after treatment with cART. The results demonstrate that

National Centre for Human Retrovirology, St Mary's Hospital, Paddington, London, UK there are differences between HTLV/HIV co-infected and mono-infected patients; notably increased immune activation, despite successful treatment with cART. It is hypothesised that co-infection creates an environmental milieu, reflected by increased immune TCA, that is associated with a higher prevalence of HTLV associated myelopathy that is observed in this group.

Published: 28 August 2015

doi:10.1186/1742-4690-12-S1-P22

Cite this article as: Dhasmana et al: Comparison of clinical, immunological and virological markers in patients with HTLV-1 / HIV-1 co-infection with those with mono-infection. Retrovirology 2015 12(Suppl 1):P22.

Submit your next manuscript to BioMed Central and take full advantage of:

- Convenient online submission

- Thorough peer review

- No space constraints or color figure charges

- Immediate publication on acceptance

- Inclusion in PubMed, CAS, Scopus and Google Scholar

- Research which is freely available for redistribution

Submit your manuscript at www.biomedcentral.com/submit 